\title{
A MULTI-CRITERIA ANALYTICAL HIERARCHY PROCESS (AHP) TO FLOOD VULNERABILITY ASSESSMENT IN BATNA WATERSHED (ALGERIA)
}

\author{
Guellouh SAMI* \\ Doctor, Laboratory LRNAT, University of Batna-2, Algeria, \\ e-mail: guellouhsami@gmail.com \\ Dridi HADDA \\ Professor, Laboratory LRNAT, University of Batna-2, Algeria, \\ e-mail: hadda.dridi@gmail.com \\ Kalla MAHDI \\ Professor, Laboratory LRNAT, University of Batna-2, Algeria, \\ e-mail: m_kalla1@yahoo.fr \\ Filali ABDELWAHHAB \\ Professor, Laboratory LRNAT, University of Batna-2, Algeria, \\ e-mail: abdelwahhabfilali@gmail.com
}

Citation: Sami, G., Hadda, D., Mahdi, K., Abdelwahhab, F. (2020). A Multi - Criteria Analytical Hierarchy Process (AHP) to Flood Vulnerability Assessment in Batna Watershed (Algeria). Analele Universităţii din Oradea, Seria Geografie, 30(1), 41-47. https://doi.org/10.30892/auog.301105-810

\begin{abstract}
A multi-criteria Analytical Hierarchy Process (AHP) analysis was carried under a geographic information system (GIS) integrating several factors, namely slope, maximum daily precipitation, for a 100 -year return period, drainage density, permeability and vegetation cover whose purpose is to better understanding, evaluate and mapping the vulnerability to flooding in Batna watershed. This analysis assesses the level of this phenomenon according to several criteria of different nature; these criteria were recorded and weighted on the same scale. The results show that several areas are extremely vulnerable requiring the implementation of priority actions to address this risk.
\end{abstract}

Key words: AHP, Batna, flood, GIS, vulnerability, watershed

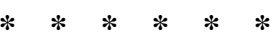

\section{INTRODUCTION}

Hydrological risks pose a threat to people and property in most parts of the world. The optimal management of floods requires prior knowledge of the cause of the phenomenon and a good mapping of its extent (Wade et al., 2008; Herman, 2009, 2010). The methodology adopted for 
the characterization and delimitation of flood vulnerability in the Batna watershed is based on multi-criteria analysis by integrating several factors where each one has a weight depending on their importance and their influence on the gravity of the phenomenon.

Multicriteria analysis is a decision support tool developed to solve complex multi-criteria problems that include qualitative and/or quantitative aspects in a decision-making process (Mendozaet al., 2000). This method makes it possible to provide answers to several difficulties posed by the evaluation (Grivault et al., 2007). We chose T. Saaty's method, which has the advantage of proposing an easily comprehensible model of data organization reflecting the natural tendency of the mind to sort the elements of a system into different levels and to group similar elements on one level to solve unstructured problems (Barczak et al., 2007).

The factors involved in the analysis depend on the availability of data. The slope is the major factor that influencing flooding; the areas of low to very low slope are areas prone to flooding and submersion. The precipitation is the factor that generates flow and triggers flooding. Rainwater accumulates in low-lying areas and converges towards the downstream; these areas represent the drainage network which can take third place in the weighting.

Permeability is explained by the lithological nature and by the land cover, waterproofing of the soil is one of the factors that favours surface flows. When water infiltration into soil is permanently reduced, the risk of surface runoff is increased (Montoroi, 2012).

Finally, the vegetation cover exerts an important limiting effect on surface runoff. It regulates stream flow and dampens low- and medium-amplitude floods. However, its effect on extreme flows caused by catastrophic floods can be reduced (Saley et al., 2005). Degraded vegetation cover is a favourable factor for surface flows and promotes the watershed's hydrological response. Runoff is strongly accentuated for soils with scattered vegetation cover (Montoroi, 2012).

We used an index parameterized approach where each parameter is in fact a numerical index translated by a code used for modeling.

\section{STUDY AREA}

The catchment area of Batna figure 1, located in eastern Algeria, covers an area of 802.68 $\mathrm{km}^{2}$, between latitudes $35^{\circ} 25^{\prime}$ and $35^{\circ} 47^{\prime}$ North and between longitudes $6^{\circ} 5^{\prime}$ and $6^{\circ} 29^{\prime}$ East.

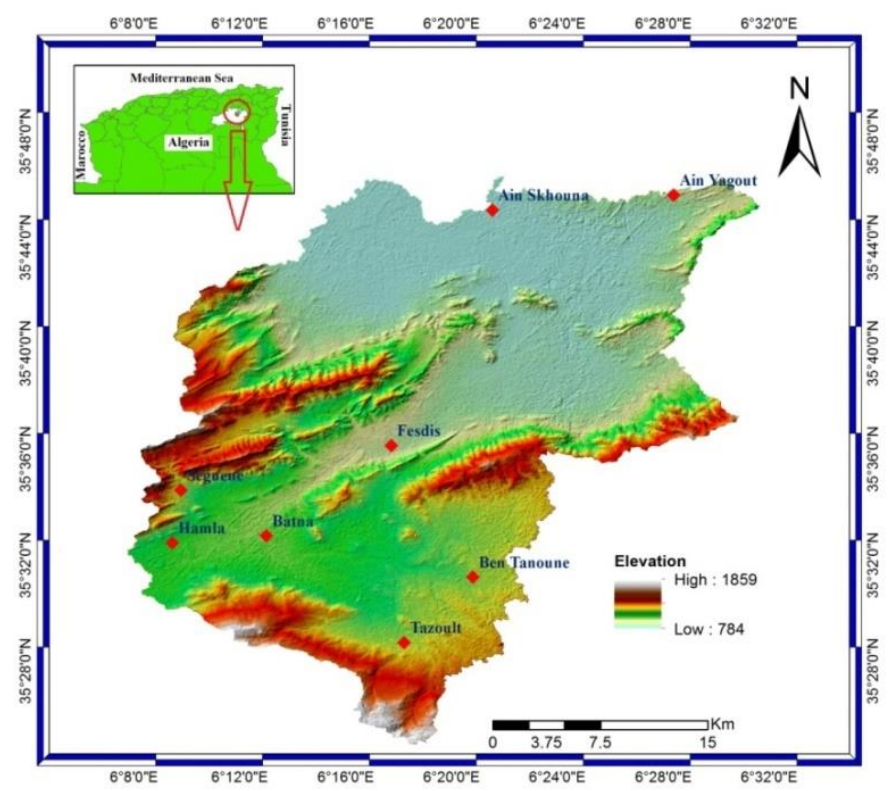

Figure 1. Study area

(Source: Guellouh Sami) 
The climate of the region is classified as semi-arid, characterized by irregular rainfall. (Sami et al., 2016). Its geography makes it possible to identify several categories of land use, each characterized by strong specificities and great diversity.

\section{MATERIALS AND METHODS}

To map the vulnerability to flooding in the Batna watershed, several thematic maps have been drawn up beforehand. The factors involved in the analysis, their sources and the method of acquisition are summarised in order of priority in the table below.

Table 1. Data Sources and Acquisition Method

\begin{tabular}{|c|c|c|}
\hline Parameters & Data Sources & Acquisition Method \\
\hline Slope & DEM & Extraction \\
\hline rainfall & $\begin{array}{c}\text { Rainfall National Water Resources } \\
\text { Agency (ANRH) }\end{array}$ & Interpolation \\
\hline Drainage density & DEM & Extraction \\
\hline Permeability & $\begin{array}{c}\text { Geological map of Algeria } \\
1 / 500,000\end{array}$ & Scan \\
\hline vegetation cover & Satellite image $30 \mathrm{~m}$ & Supervised classification \\
\hline
\end{tabular}

The adopted method is AHP. It's i a popular method used as a tool for multi-criteria decision making (MCDM) or as a technical estimation (Taibi and Atmani, 2017). This method has mathematical properties and allows total ranking, it requires a hierarchy of the decision problem and a pairwise comparisons of entities in every node of the hierarchy (Saaty, 1991). AHP involves the following steps: (1) structuring possible factors for the problem into a hierarchy; (2) arranging the factors for each alternative; (3) developing the criteria for alternatives; (4) evaluating the importance of alternatives; and (5) analyzing the weight of each factor (Chen et al., 2011).

Table 2. Fundamental AHP judgment scale with integers 1 to 9 and their definition

\begin{tabular}{|c|c|c|}
\hline Jugement & Definition & Comment \\
\hline 1 & Equal importance & Two activities contribute equally to the objective \\
\hline 3 & Moderate importance & $\begin{array}{c}\text { Experience and judgment slightly favor one activity } \\
\text { over another }\end{array}$ \\
\hline 5 & Strong importance & $\begin{array}{c}\text { Experience and judgment strongly favor one activity } \\
\text { over another. }\end{array}$ \\
\hline 7 & $\begin{array}{l}\text { Very strong or demo-started } \\
\text { importance }\end{array}$ & $\begin{array}{c}\text { An activity is favored very strongly over another; its } \\
\text { dominance demonstrated in practice. }\end{array}$ \\
\hline 9 & Extreme importance & $\begin{array}{l}\text { The evidence favoring one activity over another is of } \\
\text { the highest possible order of affirmation.. }\end{array}$ \\
\hline $2,4,6$ et 8 & $\begin{array}{l}\text { Values associated with } \\
\text { intermediate judgments }\end{array}$ & $\begin{array}{l}\text { Where a compromise is } \\
\text { necessary. }\end{array}$ \\
\hline
\end{tabular}

Table 3. Pair Comparison Matrix (Judgment Matrix)

\begin{tabular}{|c|c|c|c|c|c|}
\hline & Slope & rainfall & Drainage density & Permeability & vegetation cover \\
\hline Slope C1 & 1 & 2 & 4 & 5 & 7 \\
\hline Rainfall C2 & $1 / 2$ & 1 & 3 & 5 & 6 \\
\hline Drainage density C3 & $1 / 4$ & $1 / 3$ & 1 & 3 & 4 \\
\hline Permeability C4 & $1 / 5$ & $1 / 5$ & $1 / 3$ & 1 & 3 \\
\hline vegetation cover C5 & $1 / 7$ & $1 / 6$ & $1 / 4$ & $1 / 3$ & 1 \\
\hline Total & 2.09 & 3.7 & 8.58 & 14.33 & 21 \\
\hline
\end{tabular}

We divided each element of the matrix by the column total by the total value of the column and we calculated the average of the elements of each row. 


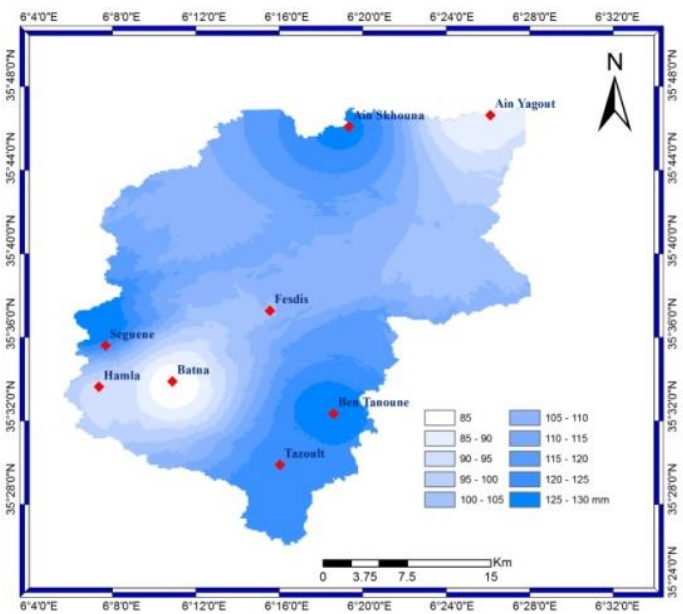

(A) Rainfall

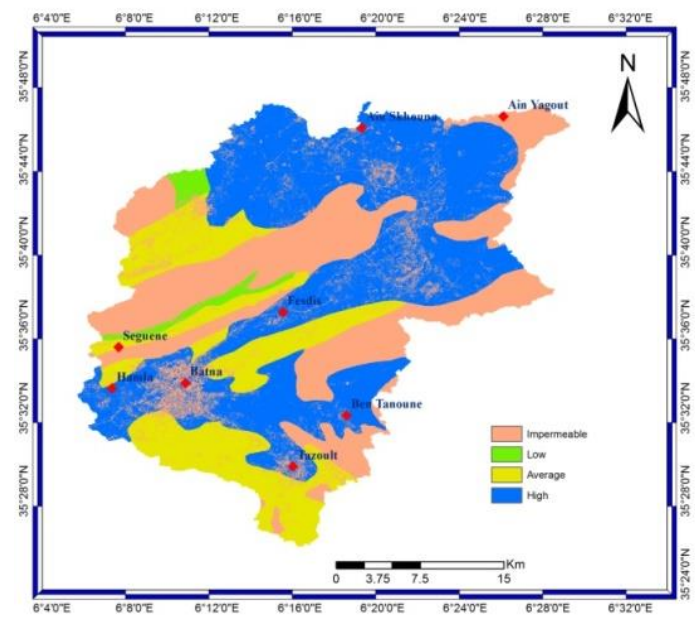

(C) Permeability

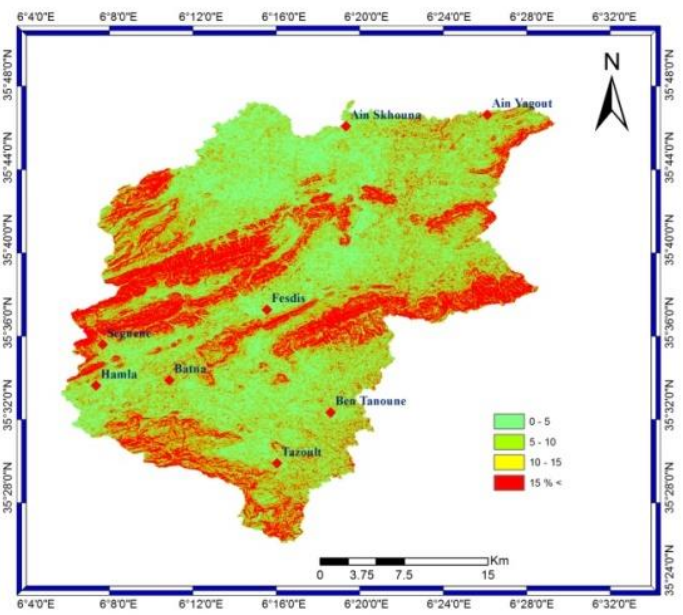

B) Slope

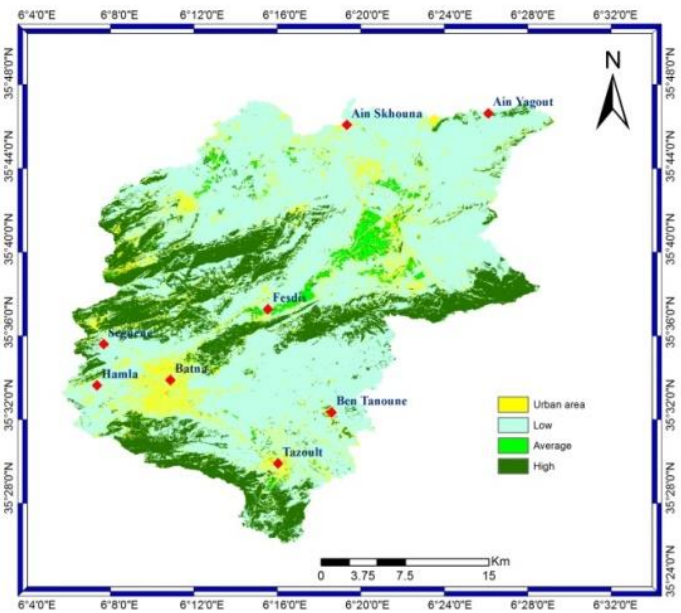

(D) vegetation cover

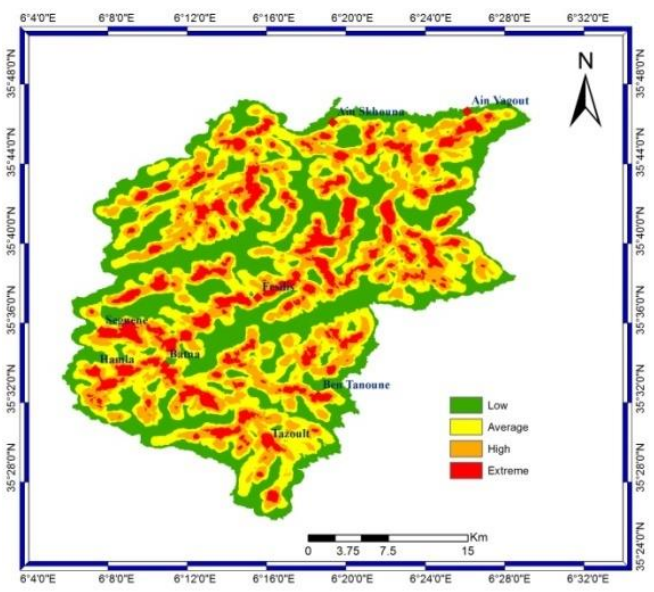

(E) Drainage Density

Figure 2. Thematic maps 
Table 4. Determination of the weight of each criterion

\begin{tabular}{|c|c|c|c|c|c|c|}
\hline & $\mathrm{C} 1$ & $\mathrm{C} 2$ & $\mathrm{C} 3$ & $\mathrm{C} 4$ & $\mathrm{C} 5$ & $\begin{array}{c}\text { The } \\
\text { weight }\end{array}$ \\
\hline $\mathrm{C} 1$ & 0.47 & 0.54 & 0.46 & 0.35 & 0.33 & 0.437 \\
\hline $\mathrm{C} 2$ & 0.24 & 0.27 & 0.34 & 0.35 & 0.28 & 0.302 \\
\hline $\mathrm{C} 3$ & 0.12 & 0.09 & 0.11 & 0.20 & 0.19 & 0.142 \\
\hline C4 & 0.095 & 0.054 & 0.038 & 0.07 & 0.14 & 0.075 \\
\hline C5 & 0.068 & 0.045 & 0.029 & 0.023 & 0.047 & 0.041 \\
\hline Total & 1 & 1 & 1 & 1 & 1 & 1 \\
\hline
\end{tabular}

The results from AHP are scores equal to 1 (Griot, 2007).After calculating the relative importance and determining the weight of each factor in the hierarchy, the vulnerability is calculated using the following formula:

Vulnerability $=0.437$ Slope +0.302 rainfall +0.142 Drainage density +0.075 Permeability +0.041 vegetation cover.

We note that the weighting for the different classes of the same criterion is based on the following principle:

Table 5. Weighting for different classes of the same criterion

\begin{tabular}{|c|c|c|c|c|c|}
\hline $\begin{array}{l}\text { Parameters } \\
\text { of Classes }\end{array}$ & C1 & $\mathrm{C} 2$ & $\mathbf{C 3}$ & $\mathrm{C} 4$ & C5 \\
\hline Classe 1 & Weight C1 X 1 & Weight $\mathrm{C} 2 \mathrm{X} 1$ & Weight C3 X 1 & Weight C4 X 1 & Weight C5 X 1 \\
\hline Classe 2 & Weight C1 X $1 / 2$ & Weight C2 X $1 / 2$ & Weight C3 X 1/2 & Weight C4 X 1/2 & Weight C5 X 1/2 \\
\hline Classe 3 & Weight C1 X $1 / 3$ & Weight C2 X 1/3 & Weight C 3 X $1 / 3$ & Weight C4 X 1/3 & Weight C5 X 1/3 \\
\hline Classe 4 & Weight C1 X ${ }^{1 / 4}$ & Weight C2 X ${ }^{1 / 4}$ & Weight C3 X 1/4 & Weight C4 X 1/4 & Weight C5 X 1/4 \\
\hline
\end{tabular}

\section{RESULTS AND DISCUSSIONS}

With Arc GIS software and its extensions, we were able to attach weights to the different thematic maps and to create the map of vulnerability to floods in Batna watershed.

To verify the level of consistency of judgments and to ensure that the data are logically related to each other, a consistency ratio $\mathrm{R}$ below 0.10 is considered permissible, the higher ratio of 0.10 indicates a higher level of inconsistency. In our case $R=0.048$ (figure 3,4 ).

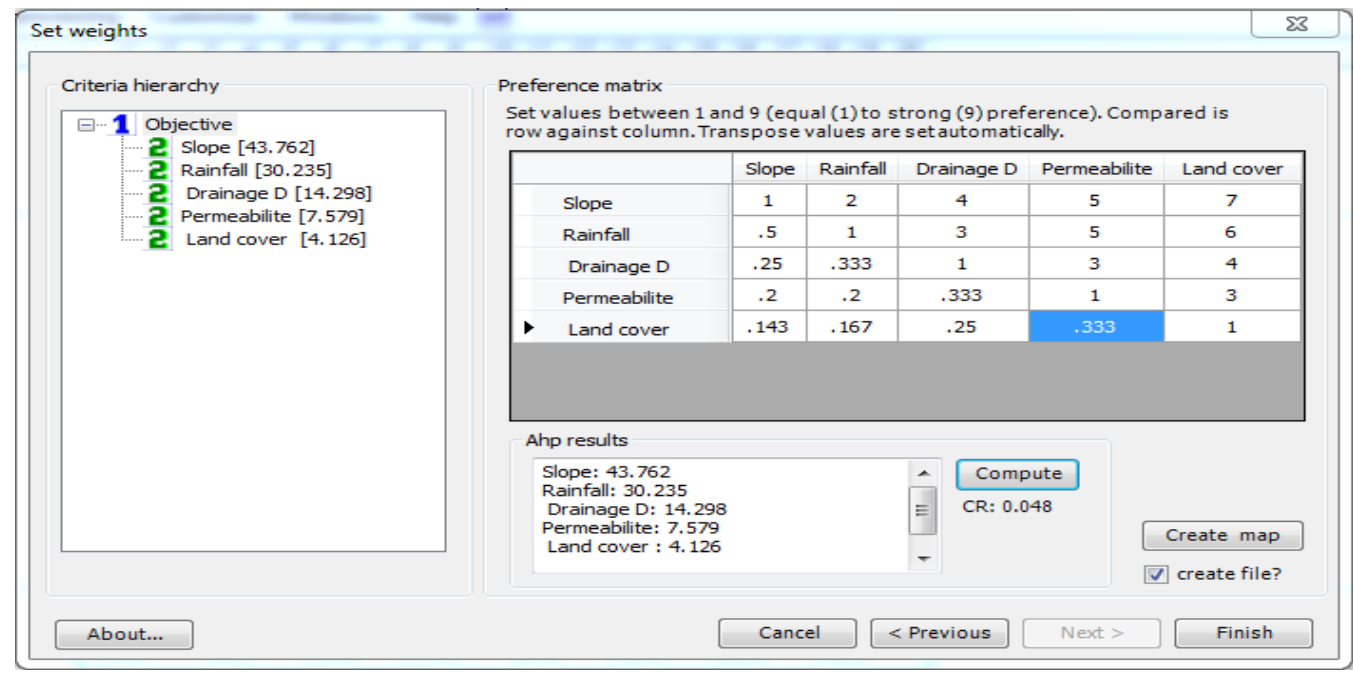

Figure 3. AHP extension under Arc Gis 


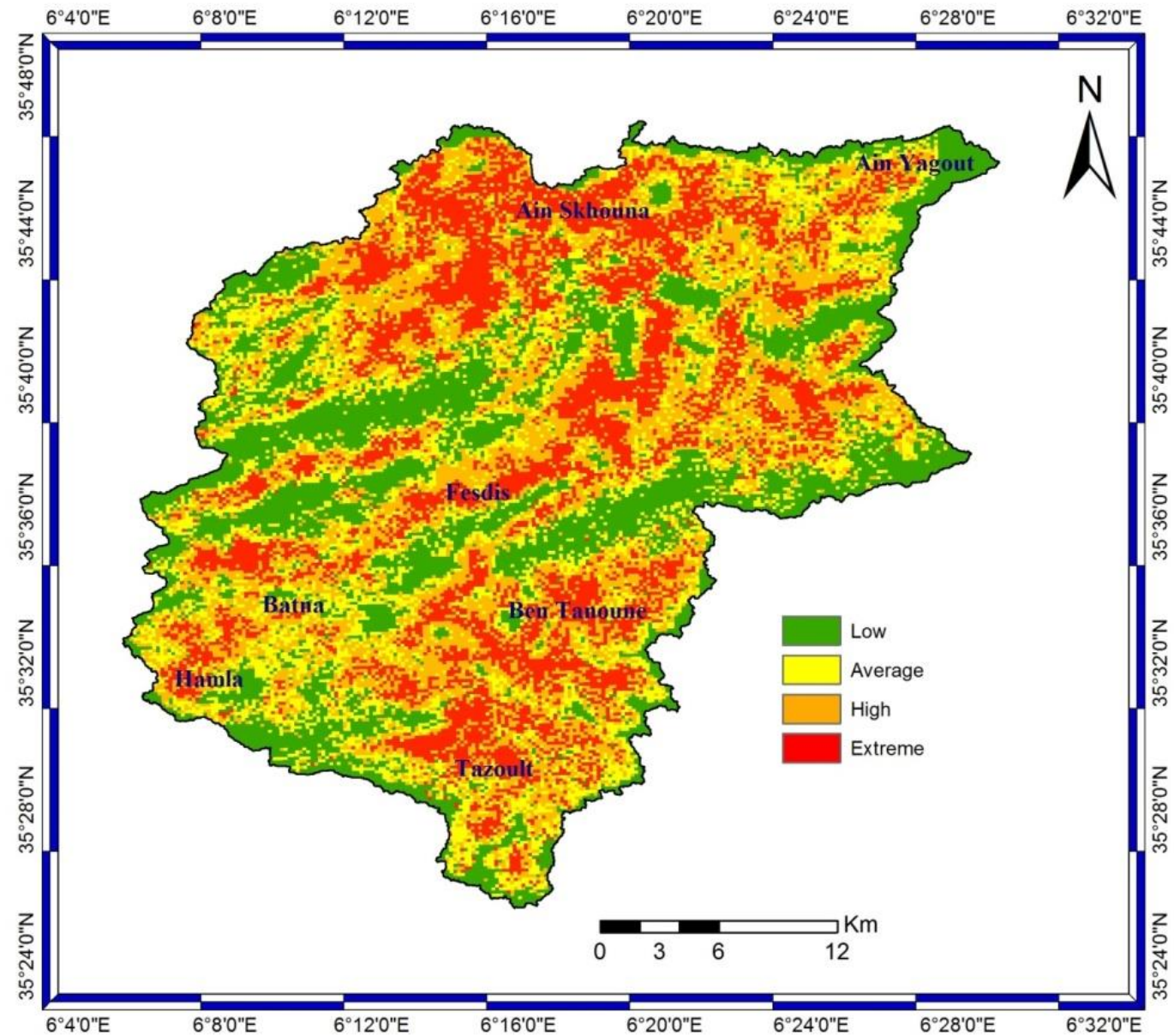

Figure 4. Vulnerability to flooding in the Batna watershed

The vulnerability to flooding in the Batna watershed is classified into four levels, from low to very strong going through the medium and the strong.

The map shows that several areas are listed in a strong and very strong vulnerability, notably Tazoult, Batna, the plain of Fesdis and Ain Skhouna, and this essentially comes back to the very low slope (less than 5\%). The use of multi-criteria analysis under a GIS can be a useful tool for the spatialization of this vulnerability.

\section{CONCLUSION}

Accurate and prior knowledge of the physical characteristics of the study area is an essential step in the study of flood vulnerability.

The hierarchical multi-criteria analysis method provided reliability in delineating flood vulnerability by weighting each criterion involved in the analysis several areas are in significant vulnerability (Batna, Tazoult, Fesdis Plain and Ain Skhouna Plain) and its mainly due to the nature and form of the physical characteristics which have a significant influence on the flows, particularly the very low slope $(0-5 \%)$ and the characteristics of the river system related to the drainage density which strongly favor the duration of submersion. 


\section{REFERENCES}

Barczak, A., \& Grivault, C. (2007). Système d'Information Géographique pour l'évaluation de la vulnérabilité au risque de ruissellement urbain. NOVATECH 2007.

Chen, Y. R., Yeh, C. H., \&Yu, B. (2011). Integrated application of the analytichierarchyprocess and the geographic information system for flood riskassessment and flood plain management in Taiwan. Natural Hazards, 59(3), 1261-1276.

Griot, C. (2007). Vulnérabilité et transport de matières dangereuses: une méthode d'aide à la décision issue de l'expertise de la Sécurité Civile. Cybergeo: European Journal of Geography.

Grivault, C., \& Barczak, A. (2007). Evaluation multicritère de la vulnérabilité des territoires aux risques de transport routier de matières dangereuses. Rencontre Internationales Géomantique et territoire. SAGEO'2007.

Herman, G. V. (2009). Omul şi modificările antropice din Câmpia Someşului [The man and anthropogenic changes in Somes Plain], Editura Universităţii din Oradea, 227 pag., ISBN 978-973-759-981-0, Oradea.

Herman, G. V. (2010). Using Geographical Information (GIS) System for Management of Flood Risks in the Somes Plain. In Cross-Border Partnership with Special Regard to the Hungarian - Romanian - Ukrainian Tripartite Border, Book Editors Ioan Horga, Istvan Suli Zakar, Publishing House University of Debrecen Press, p. 175 -179.

Mendoza, G. A., Macoun, P., Prabhu, R., Sukadri, D., Purnomo, H., \& Hartanto, H. (2000). Application de l'analyse multicritère à l'évaluation des critères et indicateurs. CIRAD-Foret and CIFOR.

Montoroi, J. P. (2012). Rôle des sols sur la génèse des inondations. In Publications du symposium européen sur les problèmes actuels de la protection contre les inondations de mars 2012.

Saaty, T. L. (1991). Método de Análise Hierárquica São Paulo, McGraw-Hill, Makron, 367 p.

Saley, M. B., Kouamé, F., Penven, M. J., Biémi, J., \& Kouadio, B. H. (2005). Cartographie des zones à risque d'inondation dans la région semi-montagneuse à l'Ouest de la Côte d'Ivoire: apport des MNA et de l'imagerie satellitaire.

Sami, G., Hadda, D., \& Mahdi, K. (2016). Estimation and mapping of extremerainfall in the catchment area of Batna (Algeria). Analele Universităţii din Oradea, Seria Geografie, 26(1), 107-117.

Taibi, A., \& Atmani, B. (2017). Combining Fuzzy AHP with GIS and Decision Rules for Industrial Site Selection. International Journal of Interactive Multimedia \& Artificial Intelligence, 4(6), 60-69.

Wade, S., Rudant, J. P., Ba, K., \& Ndoye, B. (2008). Télédétection et gestion des catastrophes naturelles: applications à l'étude des inondations urbaines de Saint Louis et du ravinement lié à l'érosion hydrique à Nioro-Du-Rip (Sénégal). Revue Télédétection, 8(3), 203-210.

Submitted:

May 07, 2019
Revised:

December 12, 2019
Accepted and published online February 25, 2020 